\title{
11〜12世紀シリア地方社会の裁判官 —トリポリとジャバラの場合—
}

Qādìs in the Syrian Coastal Towns of Tripoli and Jabala during the 11th-12th Centuries

\section{佐 藤 次 高 SATO Tsugitaka}

\begin{abstract}
Some Coastal towns of Syria during the 11th-12th centuries were headed by local $q \bar{a} d \bar{\imath}$ s (judges) who had acquired independence from either Fatimid, Seljuqid, or Byzantine rule. These urban states have been the objects of serious research by such scholars as Cl. Cahen, E. Ashtor, A. Havemann and U. A. Tadmurì. But as for the period when $q \bar{a} d \bar{\imath}$ s lost their independence, few references are made to their role in Muslim urban life. The cases of Tripoli and Jabala, because of ample information, may provide us with a means to better our understanding of local $q \bar{a} d \underline{\imath} \bar{s}$ in medieval Islamic societies.
\end{abstract}

During the years 1066-1070 the qādi office of Tripoli was established by Amin al-Dawla, a Shi'ite jurist of great reputation, from the 'Ammār family. Jabala also had a wise $q \bar{a} d \bar{\imath}$ named Manșūr, who managed the judicial affairs among Muslims under Byzantine rule. His status ( $R a^{\prime} \bar{\imath}$ s Jabala) was inherited by his son, Ibn Șulayḥa, who maintained independence against the pressure of the Seljuqids until the arrival of the Crusaders. Ibn Șulayha, faced with a strong siege by the Crusaders, was forced to transfer sovereignty to Tripoli; but another $q \bar{a} d \bar{\imath}$, Ibn al-Naqqār, then continued to manage judicial affairs in Jabala. Even under the Crusader rule from July 1109, Jabala was administered by an influential qā $\bar{\imath} \bar{\imath}$ named Manșūr b. Nabīl, who succeeded afterwards in delivering the town to Saladin.

These instances reveal that the $q \bar{a} d \bar{\imath}$ s of Tripoli and Jabala managed

東京大学文学部教授

Professor, Faculty of Letters, University of Tokyo 
these municipalities even during the periods when towns lost their independence. We may therefore evaluate positively the role of local $q \bar{a} d \bar{i}$ s before the Ottoman period, a time when they came to be organized more systematically into that empire's provincial administration.

はじめに

イスラム社会の裁判官（qāḍii) の役割について，マーワルディー（1058年 没）は，紛争の調停，禁治産者の後見，ワクフの管理，遺言の執行，公共の利 益の監督, 公平な裁判などをあげている。 E.ティヤンは, このような法学者 の見解をふまえてイスラムの司法制度史をはじめて総合的に研究し, アイユー ブ朝やマムルーク朝時代のカーディーは, 裁判業務のほかにスルタンの秘書や 国庫の管理などを担当することによって，行政にも参画するようになったと述 べている。これは主として中央レベルでの行政的機能を論じたものであるが， カーディーの社会的役割をさらに具体的に理解するためには，地方社会のなか のカーディーにも注目する必要があろう。

シリアの地方社会については, $\mathrm{Cl}$. カーエンの先駆的な研究以来, 町の長 (ra'is al-balad) やカーディーによる自治政権の性格をめぐってさまざまな研 究が発表されてきた。E.アシュトールは，12世紀シリアの行政問題をライー

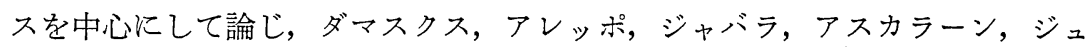
バイル，ハッラーンなどの事例を広い視点から比較検討した。また，A.ハー ヴェマンのライースとカーディー研究は，10-12世紀のシリア諸都市を対象に して，自治政権とリーダーシップの分析をさらに具体的な形でおし進めたもの といえよ 5 。一方，これと同時代のトリポリの歴史を総合的に叙述したU.A. タドムリーの著書は, 徹底した史料調査とていねいな論証にもとづく地方都市 の事例研究として注目に値する。

しかしこれらの研究は，いずれも考察の範囲を地方の有力者が自治政権を樹 立した時期に限って抢り，シリアの諸都市がビザンツや十字軍などの外国勢力 の支配下に和かれた時期についてはほとんど触れるところがない。また自治政 権の時代についても，史料の検索が不十分であるために，基本史料によって年 代や事実を修正しなければならない点がいくつも認められる。そこで本稿では， 
シリア海岸都市のトリポリとジャバラをとりあげ，両都市におけるカーディー の役割をできるだけ具体的に検討してみることにしたい。特にトリポリとジャ バラを選んだのは，11-12世紀についてはカーディーにかんする史料が比較的 豊富であり，しかも拉よそ120キロメートルを隔てた両都市は，七ルジューク 朝のシリア進出や十字軍の侵攻など大きな歴史变動のなかで，不思議な注どに 太い絆を保ち続けたからである。

な抢本稿は，現地調査にもとづくジャバラ 3 部作の第 2 部に当たるが，基本 的なねらいは前稿と同じく，地方社会の視点からイスラム史の全体を見直すこ そにある。地方の都市社会のなかでカーディーはいったいどのような役割を果 たしていたのか，この点について同時代史料をもとに新しい提言を試みること にしたい。

\section{I. トリポリのカーディー}

11世紀のはじめのシリアでは, カイロのファーティマ朝, ダマスクスのセル ジューク朝，それにビザンッ帝国の三大勢力が，海岸都市の支配権をめぐって 互いに抗争をくり返していた。ヒジュラ暦455（西暦1063）年,ファーティマ朝 の支配下にあったスール Șūr (Tyre) のカーディー, イブン・アビー・アキー ル :Ayn al-Dawla b. Abi 'Aqil は, カリフ・ムスタンスィル（在位1036一 94）への服従を拒否してファーティマ朝から独立し，465（1075）年に没する までスールの自治的な統治を続けた。イブン・アビー・アキールは商船を持っ て商売を営む資産家でもあったが，没後，スールのカーディー政権はその子供 たちによって継承され，482（1089）年にファーティマ朝がスールとサイダー を奪還するまで約27年間にわたって存続した。

この間化方のトリポリ T⿱arābulus (Tripoli) でも, アンマール Ammār 家のアミーン・アッダウラ Amin al-Dawla Abū Ṭālib al-Hasan b. 'Ammār によるカーディーの自治政権が樹立された。従来の研究は，アミー ン・アッダウラが自立した年を，ファーティマ朝の総督ムフタール・アッダ ウラが没した462（1070）年とすることで一致している。その根拠は Mir'at やKāmil の記事にあるが，それらはいずれも「462年には，アミーン・アッダ ウラはすでにトリポリの支配者」であり，「その領主 (Ṣāḥib Ṭarābulus) と して町を統治し，命令を下し，自由に振舞った」ことを示すだけである。これ 
について正確な年代を定めるのはむずかしいが，Sibț Ibn al-Jawzī (1256年 没）は，459（1066-7）年の出来事として次のような記録を残している。アレ ッポのミルダース朝君主マフムードが，ファーティマ朝と結んだ兄弟のアティ 一ヤと「戦い以外にない」状態に陥ったとき, トリポリのカーディー・イブン ・アンマール（アミーン・アッダウラ）は，「両者の間に入り，（和解の）金 額を定めて事態を収拾した」。この記事はアミーン・アッダウラがすでにかな りの政治力を保持していたことを示しているが，ここにはまだ彼がトリポリの 支配者（șāḥib あるいは ra’is）であることは明記されていない。したがって アミーン・アッダウラがトリポリの支配権を手中にしたのは，ヒジュラ暦459462年の間のことであったと推測される。

アンマール家の前身は, ファーティマ朝の創設期に軍団の主力を形成したベ ルベル人のクターマ Kutāma 族にあった。一族のアブー・ムハンマド Abū Muḥammad al-Ḥasan b. 'Ammār (390/1000年没) はカリフ・ハーキム（在 位996-1021）の宰相（wazirr）に就任すると，同族のアブー・タミームAbū Tamìm Sulaymān をダマスクスに派遣した。アブー・タミームはまもなく 総督（wālii）となってトリポリに赴任し，後にアンマール家がエジプトで権勢 を失ってからもトリポリの名家として生き残る道を開いたのである。このアン マール家のなかで最初にカーディーの職を獲得し, トリポリに自治政権を樹立 したのがアミーン・アッダウラであった。Ibn Shaddād (1285年没) は，この カーディーの事績を次のように記している。

イブン・アンマール（アミーン・アッダウラ）はシーア派の法学者 (faqih) であり，人々に抜きんでた聡明さと優れた見識の持ち主であった。 彼はトリポリに「知恵の館」Dār al-'Ilm を建設したが，そこには10万 冊以上の書物が収められていた。また彼は, Jirāb al-Dawla の『魂の 蘇生』Tarwīh al-Arwāh と題する書物の編纂を行った (șannafa)。

これによれば, アミーン・アッダウラはシーア派のカーディーであり，彼は カリフ・ハーキムがカイロに建設した「知恵の館」Dār al-Ḥikma あるいは Dār al-'Ilm と同名の研究機関を建設したことになる。それでは，ここでいう 書物の編纂とはどらいら意味であろらか。タドムリーは，アミーン・アッダゥ ラがジラーブ・アッダウラと同名の書を著したのであろらと推測しているが， 私は Tarwiḥの写本を確定し，これに注釈をつけるなど文字通りの編纂作業を 
指すものと思う。

464年ラジャブ月（1072年3-4月）にアミーン・アッダウラが没すると，息子 のシャムス・アルムルク Shams al-Mulk Muhammad がまだ幼かったため に，アミーン・アッダウラの兄弟アブー・アルカターイブ Abū al-Katā'ib Aḥmad と侽のジャーラール・アルムルク Jalāl al-Mulk Abū al-Ḥasan 'Ali との間に後継者争いが発生した。ジャラール・アルムルクは，アミール・ イブン・ムンキズ Sadid al-Mulk Ibn Munqidh の助力を得てアブー・アルカ ターイブをトリポリから追放し，叔父の地位を継承することに成功した。彼は 492年シャーバーン月末（1099年 7 月半ば）に没するまで，30年近くにわたり， トリポリのカーディーとしてこの町の統治を続けた。Ibn al-Athir （1233年 没）によれば，「彼は町の秩序を見事に維持し，叔父の死による影響が現われ ることはなかった」といわれる。その政権維持の方針は，「(エジプトの宰相) アミール・アルジュユーシュに服することなく，（ダマスクスの）トルコ人 al-Atrāk に贈物をし, 彼らと友好関係を保った」と伝えられるように，自らは シーア派であっても，スンナ派のセルジューク勢力と結び，それによってエジ プトのファーティマ朝を牽制することにあった。

ジャラール・アルムルクが政権を握ってから10年後の473 (1080-1) 年, アン ティオキアとジャバラのビザンツ総督フィラレトス Philaretos Brachamios がジャバラのカーディーを逮捕する事件が発生した。これれを知ったジャラール ・アルムルクは, フィラレトスに使いを送り, ジャバラのカーディーの釈放と カーディー職への復帰を実現させた。この見返りにジャラール・アルムルクが ジャバラの明け渡しを求めると, ジャバラのカーディーはこれに応えて海上か らの派兵を求めたといら。この間の状況を Sibṭ Ibn al-Jawzī は次のように 述べる。

イブン・アンマール（ジャラール・アルムルク）は, ‘Ayn al-Zamān のラカブをもつ奴隷 (ghulām) にトリポリ軍を構成していた300のトルク マーンと水兵（al-Baḥrāniya）の一団をつけてジャバラへ派遣した。夜， 援軍が到着すると，カーディーは睡眠中の見張りを欺いて氷兵に門を開き， 彼らを市内に導き入れた。彼らは［アッバース朝のカリフ］al-Muqtadi と [セルジューク朝のスルタン $]$ Malik Shāh のためにフトバを行った。 この記事によれば, トリポリのカーディーは, 小規模ではあるが, トルコマ 
ーンなどからなる騎馬軍と水軍とを保持していたことになる。ただこのトリポ リ軍 (Jund Țarābulus) は, 町の若者を中心にして編成されたダマスクスやア レッポのアフダース(aḥdāth) とは異なり，カーディーの所有する軍隊 (jund) であった点が特徴であろう。いずれにせよ，この征服を機にジャバラは和よそ 115年ぶりにビザンツの支配を脱し，トリポリの支配下に組み込まれることに なった。それでは，ここに登場したジャバラのカーディーとは，いったいどの ような人物だったのであろらか。次に同じシリアの海岸都市ジャバラについて 検討してみることにしたい。

\section{II. ジャバラのカーディー}

アラブ軍による征服（17/638年）以来ムスリム政権の支配下にあったジャバ ラ Jabala は, 357 (968) 年，シリアに侵入したニケフォロス 2 世の攻撃によ りビザンツの支配に服することになった。 ビザンッ時代のジャバラのカーディ ーについて, Ibn al-Athir は

Ibn Șulayḥa の父 Manșūr は，ビザンツがムスリムを支配していた時 代に，町の長 (Ra'is Jabala) としてムスリム間に生ずる紛争の裁決に 当たっていた。ビザンッの力が弱まり，ムスリムが支配権を得て，ジャバ ラが Șāḥib Ṭarābulus であるジャラール・アルムルクの支配下に入っ た後にも，Manșūr は慣行（'āda）にしたがって町の統治を続けた。 と述べている。ここには，ビザンツの支配時代からカーディー・マンスールが 「町の長」としてムスリムの紛争の裁決に当たっていたこと，拉よびトリポリ の支配下に入ってからも，いぜんとして町の統治者としての権限を行使し続け たことが明膫に示されている。

しかもマンスール（没年不明）の死後，父を継いでジャバラのカーディーと なったイブン・スライハIbn Șulayḥa Abū Muḥammad 'Ubayd Allāh b. Manșūr は，軍事（jundiya）を好文，軍隊（jund）を徵募して，その知勇 (shahāma) が広く知られるようになっだ 机たトリポリのジャラール・アルムルクは彼を捕らえようとしたが， Ibn alAthir によれば,

イブン・スライハはジャラール・アルムルクの意図を知ると，彼に反旗を 翻してアッバース朝カリフのフトバを揭げた。そこでジャラール・アルム 
ルクは［ダマスクスのセルジューク朝君主］Duqāq b. Tutush 飞金を贈 り，イブン・スライハの包囲を求めた。Duqāq はこれを実行したが，し かし何の勝利も得ることはできなかった。 という。つまりイブン・スライハは，公的にはアッバース朝カリフの宗主権を 認め，現実には自らの軍事力によってジャバラの独立を達成したのである。独 立の正確な年代は不明であるが，イブン・スライハはトリポリやセルジューク 朝の圧力に抗して，492（1099）年はじめに十字軍（al-Firanj）がジャバラを 包囲した時にも，まだ独立を維持していた。なお，トリポリのカーディー・ジ ヤラール・アルムルクが没し，兄弟のファフル・アルムルク Fakhr al-Mulk Abū 'Alī 'Ammār b. Muhammad が後を継いだのは，この包冊からしば らくたった492年シャーバーン月（1099年 7 月）のことであった。

ジャバラのイブン・スライハは，十字軍による第 1 回目の包囲の時には，セ ルジューク軍が接近しつつあるとの虚報を流すことによって，異教徒の軍を撤 退させることができだしかし Godfroy と Robert の二人は再三にわたって ジャバラの奪取を試み，イブン・スライハも配下の者（aṣhāâb) を率いて奮戦 したが，手持ちの兵力ではとらてい支觉きれなことを知った。そこでイブン ・スライハは，494年シャーバーン月（1101年 6 月), ダマスクスのアミール・ アターベク Zahìr al-Din A tābek に使いを送り，ジャバラの統治権をセルジ ニーク朝に譲り渡すことを提案した。その後の動きを Ibn al-Qalānisī (1160 年没）は次のように述べる。

アターベクはイブン・スライハの要求に応え，望みをかなえるために，息 子の Amir Tāj al-Mulūk Būrī を前述の海岸都市に派遣することを約束 した。君主の Shams al-Mulūk Duqāq はディヤール・バクルにいてダ マスクスには不在であり，シャッワール月はじめに戻った時には，事はイ ブン・スライハの望み通りに運んでいた。Tāj al-Mulūk は部下を率いて ジャバラに向い, 町の明け渡しが行われた。

こうして494年シャッワール月（1101年 8 月), カーディー・イブン・スライ 八はブーリーにジャバラを明け渡して町を離脱し，自ら独立を放棄したジャバ ラは新たにセルジューク朝の支配下に执かれることになった。しかしブーリー の統治はジャバラの人々には不評判であった。彼は住民に対して不正を働き， 「公正（'adl）と正義（inșāf）の慣行に外れた」政治を行ったと伝えられる。 
住民の不満は高玉り，ついに彼らはトリポリのカーディー・ファフル・アルム ルクにジャバラを任せるに足る人物の派遣を求めた。同じ494年の記 録として Kāmil には，

彼（ファフル・アルムルク）は，この要求に応えて軍隊（'askar）を派遣 した。彼らはジャバラに入ると，住民と合流し，Tāj al-Mulūk（Būrīi) およびその部下と戦いを交えた。結局，トルコ人は敗走し，ファフル・ア ルムルクの軍隊がジャバラを支配下に収めた。彼らは Tāj al-Mulūk を 捕虜にすると，彼をトリポリへと護送した。ファフル・アルムルクはこの 捕虜を丁重に扱い，ダマスクスにいる父のもとへ送り届けた。 と記されている。これによれば，セルジューク朝のジャバラ支配は短期間のう ちに終わり，ジャバラは再びトリポリの支配下に組み込まれることになった。 そしてこの体制下でのジャバラの実質的な統治の担い手を探ってみると，また もやカーディーの名が浮かび上がってくる。トリポリで学問を修めたカーディ 一・イブン・アッナッカール Ibn al-Naqqār al-Jubayrì (533/1139年没) は, ファフル・アルムルクがトリポリを脱出する501（1108）年後までジャバラに 留まり，「フトバとサラートとワクフの事をとりしきった」という。

しかし十字軍の包囲によって，トリポリとジャバラの情勢はしだい緊迫の 度を加えつつあった。498（1105）年，トゥールーズ伯のレイモンはトリポリ の包囲中に没したが，レイモンとファフル・アルムルクの間には，「トリポリ 郊外はレイモンの領有に帰すが，乙かし交通は妨げない」との協約（hudna） が結ばれていた。この協約の相手の死によって，トリポリの状況はさらに厳し さを増すことになったのである。十字軍によるトリポリ包囲が強化されると， 501 年シャーバーン月（1109年 3-4月), ファフル・アルムルクは500の騎兵と 歩兵を率いてバグダードに向い，スルタン・ムハンマドに援軍の派遣を要請し た。この交渉は順調に運んだものの，留守中の代理としてトリポリに残してお いた侽のシャムス・アルムルク Shams al-Mulk Abū al-Manāqib が, 彼に 反旗を翻してェジプトのファーティマ朝側につく事態が発生した。シャムス・ アルムルクはまもなくファフル・アルムルクの手の者（aṣhāb）に捕光られた が，バグダードから戻ったファフル・アルムルクは，トリポリ住民の動向を把 握することができず，やむなく軍を率いて北方のジャバラの町に入ったと伝光 (39) られる。 
一方，ファーティマ朝の宰相アフダルは，トリポリ住民の要求に応えて大規 模な艦隊（usțūl）を派遣したが，その到着は遅れ，502年ズー・アルヒッジャ 月11日（1109年 7 月13日)，トリポリは十字軍の前に陥落した。これに伴って 殺害を免れた男は捕虜とされ，「知恵の館」に所蔵されていた文書も略奪の対 象とされだトリポリを落とした十字軍は, 次いでジャバラを包团し, 同年ズ 一・アルヒッジャ月22日（1109年 7 月23日), ファフル・アルムルクは安全保証 (amān) をえて十字軍に町を明け渡した。ジャバラを脱出したファフル・アル ムルクは，シャイザルを経由してダマスクスの君主トグテキーンの下に身を寄 せ，バラダー川の水源地帯にあるザバダーニー al-Zabadāni とその周辺をイ クター (iqțāe $\left.{ }^{\top}\right)$ とて授与された。こうして，拈よそ半世紀近くにわたって存 続したトリポリとジャバラのカーディー政権は，軍事的な外圧を受けてあっけ なく崩壊したのである。

\section{III. サラディンによるジャバラの解放}

トリポリが武力で征服され，ジャバラが安全保証（アマーン）を条件に明け 渡されたように，十字軍によるシリア諸都市の征服にはさまざまな形態があっ た。したがって征服後もいぜんとしてムスリムが多数を占める都市もあれば， ムスリムの人口比が著しく低下した都市も少数ではあるが存在しだ。しかし J . プローワーが述べるように，確かに征服からほぼ10年間は多くの都市や城些か らムスリムが姿を消したものの, 秩序が回復され, 経済が復興するにつれてム スリムは元の都市や村に戻りはじめた。その結果, トリポリ，ジャバラ，ラタ キアなどでは，やがてムスリムが従来通りの多数派を形成するようになったの である。

それでは十字軍支配下のこれらの都市では，ムスリムの統治はどのように行 われていたのであろらか。この問題についてほとんどのアラビア語史料は沈黙 を守っているが，Kämil には次のような興味深い記録が残されている。

[584（1188）年，エルサレムを解放した］サラディン Șalāḥ al-Din が 騎士の城 (Hịṣn al-Akrād) の下に布陣したとき, ジャバラのカーディー Manșūr b. Nabil が彼の下に来て町の明け渡しを提案した。このカーデ ィーは，アンティオキアとジャバラの君主 Bohemond の下にあって，そ の言葉には信頼が招かれ，十分な尊敬と高い地位が与えられていた。彼は 
Bohemond との信頼関係にもとづいて，ジャバラととの周辺地域に住む 全ムスリムの統治に当たっていだ。

このマンスール・ブン・ナビールについては，他に史料がなく，詳しい経歴 は不明である。しかしまず何よりも，マンスールがカーディーとして人々の尊 敬を集め，ボヘモンド 3 世との信頼関係にもとづいて，ジャバラとその周辺農 村に住むムスリムの統治に当たっていた点に注目すべきであると思う。一般に 十字軍支配下の地域社会では，ムスリムの統治はカーディーに委ね，ユダヤ教 徒の統治はラビに委祆るのが慣行であったから，マンスールのようなカーディ ーはジャバラ以外の都市にもいたとみてよいであろう。

十字軍の支配下にあって，マンスールはやがてジャバラやラタキアの解放を 自らの義務と考えるようになり，サラディンに対して「ジャバラのムスリムに はすでに明け渡しの心づもりができて打ります」と述べて，町の解放を促した。 これに応えてサラディンは, タルトゥースからマルカブを経由して, 584年ジュ マーダー1月18日（1188年 7 月16日）にジャバラへ到着した。これより先に町 へ戻ったマンスールは，住民にムスリム軍の到着を知らせ，城壁に旗（a’lām） を揭げて引渡しの意を公に表明した。十字軍騎士は港に面した城砦（hișn）— 現在のローマ劇場跡一にたてこもったが，この遠征に参加した Imād al-Din al-Iṣfahānī（1201年没）によれば，

ジャバラのカーディー（Qāḍi Jabala）は彼らのために仲介役をつとめ， 人質（rahā'in）の引渡し後に，つまりアンティオキアに拘留していたジ ヤバラの住民を返還して事態を収拾し, 武器, 馬, 財宝, 穀物を引き渡す 条件で，安全保証を得るものと定めた。

のである。十字軍騎士はカーディー・マンスールの仲介を受け入れ，翌日には 城砦の明け渡しが行われたために，無血のらちにジャバラの解放が実現した。 続いてサラディンはラタキアに向い，ただちに町の包囲を開始したが，市街地 （madina）を撤収して二つの城砦にたてこもった十字軍との間に激しい戦いが 行われた。しかし形成が不利となった十字軍側はジャバラのカーディーに仲介 を要請し，安全保証（amān）の条件を定めることを求めた。マンスールはこ れにもとづいて食糧, 武器, 家畜の引渡しを条件に, 十字軍側の騎士，女性， 子供の生命を保証することで合意を取り付け，ジュマーダー 1 月27日（7 月 25

日）に解放が完了すると，二つの城砦にはイスラムの旗が掲げられた。 
先にジャバラを解放したサラディンは，町の防衛のためにシャイザルの領主， アミール・サービク・アッディーン Sābiq al-Din 'Uthmān b. al-Dāya を 配し，ラタキアには甥のタキー・アッディーン Taqi al-Din 'Umar を任じ て，町の復興と城の再建に当たらせた。また，ジャバラとラタキアの解放に当 たってマンスールが果たした功績をたたえ，「私有地（milk）を彼のワクフに 定めると共に, 先祖伝来の私有地の管理を認め, 引続きカーディーの地位を保 証した」と伝えられる。

\section{むすび}

11世紀半ば頃から12世紀はじめにかけて，スール，トリポリ，ジャバラなど のシリアの海岸都市では, ファーティマ朝, ビザンツ帝国, セルジューク朝の 三大勢力の間陌をぬって，カーディーによる自治政権が樹立された。彼らは， 町の名士として豊かな資産を所有し，騎兵や歩兵，あるいは水軍からなる武力 を背景に，本来の裁判業務ばかりでなく，社会生活の全般をとりしきる政治的 な秩序維持の任にも当たった。

しかし町の秩序維持を担らカーディーの役割は，自治政権が樹立された時期 だけに限られていたのではない。これまで検討してきたよらに，トリポリのア ミーン・アッダウラは, 自立以前からミルダース朝の権力争いを調停する力を 持っていたし，ジャバラでもイブン・スライハの父マンスールは，ビザンツ支 配下にあってすでに「ジャバラの長」と称され，早くからムスリムたちの統治 に当たっていた。またイブン・スライハの逃亡後，トリポリの支配下に入った ジャバラでは, カーディー・イブン・アッナッカールがフトバ，サラート，ワ クフの事を担当したし，さらに十字軍時代のマンスール・ブン・ナビールは， ボヘモンド 3 世からジャバラとその周辺地域の統治を委ねられていた。

一般にカーディーは，オスマン朝時代になると地方行政の重要な担い手とし て体制内に組み达まれたとされるが，それ以前の時代については行政への参画 の仕方は相対的に低く評価されてきた。しかしトリポリやジャバラの例から明 らかなように，小都市を中心とする地方社会では，自治政権の時代以外にも， カーディーは町の秩序維持を含む行政の分野で重要な役割を演じていた。カー ディーによる自治政権は，周囲の政治状況に応じて偶然に生まれたのではなく， このような日常の役割を基礎にしてはじめて樹立されたものとみるべきであろ 
う。アイユーブ朝やマムルーク朝時代の事例研究はまだ十分ではないが，地方 社会のあり方をきめ細かく理解するためには，オスマン朝以前の時代について も，カーディーの役割をもっと積極的に評価することが必要であると思う。

注

(1) Mãwardī, 70-71.

(2) E. Tyan, Histoire de l'organisation judiciaire en pays d'Islam, Leiden, 1960, pp. 424-429.

(3) Cl. Cahen, La Syrie du nord à l'époque des Croisades, Paris, 1940, pp. 194-195, 233-234, 461-462.

(4) E. Ashtor, L'administration urbaine en Syrie médiévale, Revista degli Studi Orientali, vol.36, 1956, pp. 73-128.

(5) A. Havemann, Ri’āsa und qad̄a , Freiburg, 1975.な护, 10-11世紀のイラク とイランについては, リーダーシップと忠誠心の問題を扱ったモッタへデの興味深い 研究がある。 R.P. Mottahedeh, Loyalty and Leadership in an Early Islamic Society, Princeton, 1980.

(6) U.A. Tadmuri, Ta'rīkh TTarābulus, vol. 1, Ṭarābulus, 1984.

（7）第 1 部は「ヌサイリー教徒の反乱一ジャバラ・1318年 2 月一」『東洋学報』71$1 \cdot 2,1989$ 年, $115-139$ 頁。

(8) A $A^{\imath} l \bar{a} q$, II, 165. ハーヴェマンは, Kāmil, X, 60 の記事によって, イブン・アビ 一・アキールの独立を462年としているが (Havemann, Ri'āsa，S. 106), Kāmil の 記事は462年にはこの人物がすでにスールを支配していたことを述べるだけである。

(9) Ibn al-Qalānisì, 197. イブン・アビー・アキールによる商船の所有については, S.D. Goitein, Letters of Medieval Jewish Traders, Princeton, 1973, p. 158; id., A Mediterranean Society, vol. 1, Berkeley and Los Angeles, 1967, p. 296 を参 照。

(10) Havemann, Ri'āsa, S.107; P. M. Holt, The Age of the Crusades, London, 1986, pp. 70-71; The Encyclopaedia of Islam, new edition (以下, E.I.n と略 記), s.v. 'Ammār.

(11) Mir'āt (Ibn al-Qalānisī, Leiden ed., n.1); Kāmil, X, 60, 71; Yāqū $t, \mathrm{I}$, 105.

(12) Mir'āt, Ankara, 133.

(13) U.A.Tadmuri, Ta'rīkh TTarābulus, p. 337f. な拉アンマール家については,

Ibn al-Șayrafī, 33-34; Kämil, X, 71. cf. Holt, The Age of the Crusades, p. 71; M.D.Yusuf, Economic Survey of Syria during the Tenth and Eleventh Centuries, Berlin, 1985, pp. 115, 138. 
(14) A'lāq, II, 107. cf. Ibn al-Qalānisì, 262. Jirāb al-Dawla は本名を Aḥmad b. Muhammad といい, カリフ・ムクタディル（在位908-932）時代の文人であった。 C.Brockelmann, Geschichte der Arabischen Literatur, S.I, Leiden, 1937, S.599; Tadmuri, Ta'rīkh Tarābulus, p. 356.

(15) Tadmuri, Ta'rīkh Tarābulus, p. 356.

(16) Kāmil, X, 71;Abū al-Fid̄̄', II, 188; Zubda al-Halab, II, 35; A'lāq, II, 108. Yāqūt は, アミーン・アッダゥラの侽をジャラール・アッディーンとしている が ( $Y \bar{a} q \bar{u} t, \mathrm{II}, 105)$ ，これは明らかな誤りである。またタドムリーは，ジャラール・ アルムルクとアブー・アルカターイブをともにアミーン・アッダウラの兄弟としてい るが (Tadmurī, Ta'rīkh Tarābulus, p. 359), Ibn al-Athir によれば, ジャラール ・アルムルクのイスムは 'Ali b. Muḥammad b. 'Ammār であり,アミーン・アッダ ウラの侽に当たる (Kāmil, X, 71)。な竹ジャラール・アルムルクについては, M. G. Wiet, Une inscription d'un prince de Tripoli de la dynastie des Banu 'Ammar, Mémorial Henri Basset II, Paris, 1928, pp. 279-284 を参照。

(17) Kāmil, X, 71. cf. $A \nmid l \bar{a} q$, II, 108.

(18) Ibn al-Qalānisì, 182.

（19） Philaretos は，アラビア語史料では，al-Firdūs あるいはal-Filārdūs と表記さ れる (Kãmil, X, 138, 139, 413; Zubda al-Halab, II, 86)。Philaretos については, A.A.Vasiliev, Byzance et les Arabes, Tome III, Bruxelles, 1935, pp. 122-123, 143-144を参照。なお，タドムリーはこの事件を469年のこととしているが (Ta'rikh Tarābulus, p. 364)，典拠は示されていない。

(20) Mir'āt, Ankara, 208.

(21) Cl.Cahen, Mouvements populaires et autonomisme urbain dans L'Asie musulmane du moyen age, I, Arabica, vol.5, 1958, pp. 225-250; Ashtor, L'administration, pp. 118-121; Havemann, Ri’āsa, SS. 89-104. 大川原香子「ヒジ ュラ 5 〜 世紀のアレッポに怙ける都市自治について一特にライース職の役割を通し て一」『寧楽史苑』29, 1984年, 26-49頁。

(22) T. Sato, The Syrian Coastal Town of Jabala, Tokyo, 1988, pp. 38-41.

(23) Kāmil, X, 310. Manșūr の息子 Ibn Șulayḥa については, Yāqūt には Ibn Dali`a とあり (II, 105), Siyar には Ibn Șulay`a とあるが (XIX, 298)，ここで は同時代史料にしたがって Ibn Șulayḥa の呼称で統一する。

（24）Siyar によれば,イブン・スライハは騎士道 (furūsiya) を好んだとある（XIX， 298)。

(25) Kāmil, X, 310; Yāqūt, II, 105.

(26) Kāmil, X, 310.

（27）ハーヴェマンはイブン・スライハの反乱を494年のこととしているが (Havemann, Ri’ āsa, SS. 107-108), 反乱は明らかに十字軍によるジャバラ包囲前のことである 
(Kämil, X, 310)。

(28) Kämil, X, 310. Godfroy of Lorraine と Robert of Flanders による第 1 回 目のジャバラ包囲は, 492 (1099) 年のはじめに行われた（M. W. Baldwin ed., $A$ History of the Crusades, vol. 1, Madison, 1969, pp. 328-329; Sato, The Syrian Coastal Town of Jabala, p. 43)。

(29）'Azīm $\vec{\imath}, 360 ; A^{\prime} l \bar{a} q$, II, 108. タドムリーは十字軍のジャバラ包囲をジャラール・ アルムルクの没後としているが，実際の順序は逆である（Tadmuri, Ta'rīkh Tarābulus, p. 375)。

(30) Kämil, X, 310.

(31) Kāmil, X, 311; Siyar, XIX, 299.

(32) Ibn al-Qalānisī, 226.

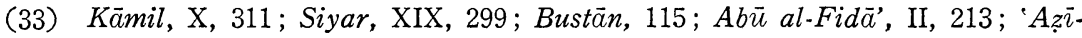
$m \bar{\imath}, 361$. イブン・スライハは部下 (aṣhāb) や近従 (asbāb) を伴い, 家畜 (kurā), 駄獣 (dawābb)，財産（māl）を持ってジャバラを脱出し，ダマスクスからバグダー ドに向かったが，スルタン・バルキャールクによってすべての財産を没収された（Ibn al-Qalänisī, 226 ; Kämiı, X, 307-308, 311-312 ; Siyar, XIX, 299; Muntazam, IX, 124)。

(34) Ibn al-Qalānisī, 226; Kāmil, X, 312;Abū al-Fid̄̄ं, II, 213.

(35) Kāmil, X, 312.

(36) Tahdhib, IV, 356-357.

(37) Mir'āt, VIII, 13.

(38) Ibn al-Qalānisì, 257-258; Kāmil, X, 452-453; $A^{*} l \bar{a} q$, II, 110-111. この反乱 の主体については，シャムス・アルムルクがエジプトに対する忠誠のしるし（shi'ār） を明らかにしたとする史料（Ibn al-Qalānisī, 257；Kāmil，X，452）と，トリポリ の住民がエジプトへの忠誠を宣したとする史料 ( $A^{\prime} l a \tilde{q} q$, II, 109) とに分かれているが， 反乱に町の住民の意向が反映していたことは確かであろら。cf. Tadmuri, Ta'rīkh Țarābulus, p. 433.

(39) Kāmil, X, 452; A'lāq, II, 111; Ibn al-Furāt, VIII, 78.

(40) Ibn al-Qalānisì, 262; A'lāq, II, 111; Mir'āt, VIII, 27;Kāmil, X, 475 ; Bughya, 158-159.

(41) Mir’āt, VIII, 27-28; Usāma, 96; Bustān, 116; 'Až̄imī, 370. なお Kāmil (X, 476) とBughya (158-159) には，503年ズー・アルヒッジャ月にファフル・アルムル クのいるジュバイルが陷落したとあるが，明らかに502年ジャバラの䛊りである。

(42) B.Z. Kedar, The Subjected Muslims of the Frankish Levant, J.M. Powell ed., Muslims under Latin Rule, 1100-1300, Princeton, 1990, pp. 135-174.

(43) J. Prawer, Social Classes in the Crusader States: the "Minorities", N. P. Zaccar and H.W. Hazard eds., A History of the Crusades, vol.5, Madison, 
1985, p. 61.

(44) Kämil, XII, 7. See Cahen, La Syrie du nord, p.428; Kedar, The Subjected Muslims, pp. 141-142.

(45) J. Riley-Smith, The Survival in Latin Palestine of Muslim Administration, P. M. Holt ed., The Eastern Mediterranean Lands in the Period of the Crusades, Warminster, 1977, p. 10.な特ケダルも，十字軍支配以前のトリポリや ジャバラのカーディーを引合いに出して，マンスールの事例を例外とすべきではない と述べている (Kedar, The Subjected Muslims, pp. 142-143)。

(46) al-Fath al-Qussi, 228.

(47) Kämil, XII, 7-8; al-Fatḥ al-Qussī, 233.

(48) al-Fatḥ al-Qussi, 233.

(49) al-Fatḥ al-Qussī, 233; Kāmil, XII, 8; Nawādir, 89-90; Zubda al-Halab, III, 103; Ibn Abì al-Hayjā', fol.188v; Abū al-Fidà', III, 73; Bustān, 147; Mufarrij, II, 255-256, 258-259; Bar Hebraeus, 328; A'lām, 84-85, 87.

(50) Nawādir, 89-90; Kāmil, XII, 9; Zubda al-Ḥalab, III, 103; Ibn Abĩ al-

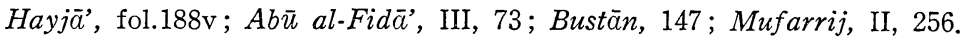

(51) Kāmil, XII, 8-9; Abū al-Fidē', III, 74.

(52) al-Fath al-Qussi, 234; Mufarrij, II, 259.

(53） 例えば, E. I. n., s. v. Kāạị ; R. Levy, Social Structure of Islam, Cambridge, 1962, p.339f. ; I. M. Lapidus, A History of Islamic Societies, Cambridge, 1988, pp. 324-325を参照。

\section{主 要 史 料}

Abū al-Fid̄̄': Abū al-Fidā', Mukhtașar fì Akhbār al-Pashar, 4vols., al-Qāhira, $1325 \mathrm{H}$.

A'lām: anon., al-A'lām wal-Tabyinn fī Khurūj al-Firanj, S. Zakkār ed., Dimashq, 1981.

$A^{\prime} l \bar{q} q$ : Ibn Shaddād Abū 'Abd Allāh, al-A'lāq al-Khațira fĩ Dhikr Umarā' al-

Shām wal-Jazīra, vol.2, S.al-Dahhān ed., Dimashq, 1963.

'Ażimī: Muḥammad al-'Azimì, Ta'rīkh Halab, I.Za'rūr ed., Dimashq, 1984.

Bar Hebraeus: Bar Hebraeus, Chronography, English tr. by E. A. Wallis Budge, London, 1932.

Barq: 'Imād al-Din al-Ișfahāni, Kitāb al-Barq al-Shāmī, MS. Bodleian Library, Bruce 11, Marsh 425.

Bughya: Ibn al-Adim, Bughya al-Talb fī Ta'rīkh Halab, Ali Sevim ed., Ankara, 1976.

Bustān: anon., Une chronique Syrienne du VIe/XII ${ }^{e}$ siècle: "Bustān Al-Jāmi", 
Cl. Cahen ed., BEO., vols.7-8, 1937-38.

al-Fatḥ al-Qussī: 'Imād al-Din al-Ișfahānī, al-Fatḥ al-Qussī fì al-Fatḥ al-Qudsì, M.

M.Ṣubḥ ed., n.p., 1965.

Ibn Abī al-Hayjā': Ibn Abì al-Hayjā', Ta'rīkh Ibn Abī al-Hayjā', MS. Aḥmadiya,

Tunis (Ma'had al-Makhțūtāat al-'Arabiya, Ta'rikh 945).

Ibn al-Furāt: Ibn al-Furāt, Ta'rīkh al-Duwal wal-Mulūk, vols. 7-9, Q. Zarīq ed., Bayrūt, 1936-42.

Ibn al-Qalānisī: Ibn al-Qalānisî, Ta'rīkh Dimashq, S. Zakkār ed., Dimashq, 1983.

Ibn al-Șayrafĩ: Ibn al-Ṣayrafī, al-Ishāra ilā man nāla al-Wizāra, A.Mukhliṣ ed., al-Qāhira, 1924.

Kāmil: Ibn al-Athìr, al-Kāmil fì al-Ta'rīkh, C. J. Tornberg ed., 12 vols., Leiden, 1853 ; repr. Bayrūt, 1965-66.

Māwardī: al-Māwardī, al-Aḥkām al-Sulțānīya, al-Qāhira, 1966.

Mir'āt: Sibț Ibn al-Jawzì, Mir'āt al-Zamān fī Ta'rīkh al-A'yān, vols. VIII-1,2, Hyderabad, 1951-52; Ankara, 1968.

Mufarrij: Ibn Wāșil, Mufarrij al-Kurūb fī Akhbār Banī Ayyūb, vols.1-5, J.al-

Shayyāl and H.M.Rabi' eds., al-Qāhira, 1953-77.

Muntazam: Ibn al-Jawzi, al-Muntazam fĭ Ta'rīkh al-Mulūk wal-Umam, vols. 5-10, Hyderabad, $1357-58 \mathrm{H}$.

Nāṣir Khusraw: Nāṣir Khusraw, Șafar Nāma, Berlin, 1340H.

Nawādir: Ibn Shaddād Bahā' al-Din, al-Nawādir al-Sulțānīya, J.al-Shayyāl ed., al-Qāhira, 1964.

Rawḍatayn: Abū Shāma, Kitāb al-Rawdatayn fī Akhōār al-Dawlatayn, 2 vols., M.H. Aḥmad ed., al-Qāhira, 1956-62.

Sañ̄ al-Barq: al-Bundārī, Sanā al-Barq al-Shāmī, F.al-Nabrāwì ed., al-Qāhira, 1979.

Siyar: al-Dhahabi, Siyar A'lām al-Nablā', 23 vols., Sh.al-Arnūt ed., Bayrūt, 1981-85.

Tahdhīb: Ibn Badrān, Tahdhīb Ta'rīkh Ibn 'Asākir, 6 vols., Dimashq, 1329-49H. Usāma: Usāma b. Munqidh, Kitāb al-I'tibār, P.K.Hitti ed., Princeton, 1930. Yāqūt: Yāqūt al-Ḥamawi, Mưjam al-Buldān, 5 vols., Bayrūt, 1955-57.

Zubda al-Halab: Ibn al- Adim, Zubda al-Ḥalab min Ta'rīkh Halab, 3vols., S. al-Dahhān ed., Dimashq, 1951-68. 